Reyes, A-E. and Dueñas, J-M. Medicinal gardens as an educational strategy

in the teaching of the natural sciences: A pedagogical proposal

\title{
Medicinal gardens as an educational strategy in the teaching of the natural sciences: A pedagogical proposal
}

\author{
Adriana-Elizabeth Reyes \\ Adjunct High School Teacher, District Education Secretary, Bogotá (Colombia). \\ Jorge-Manuel Dueñas* \\ Universitat Rovira i Virgili, Department of Psychology, Division of Developmental and Educational Psychology, Tarragona (Spain). \\ *Corresponding Author: jorgemanuel.duenas@urv.cat \\ Received : 2020-06-23 \\ Revised : 2021-01-27 \\ Accepted : 2021-02-26 \\ $10.46303 /$ ressat.2021.2
}

\begin{abstract}
How to cite this paper: Reyes, A-E. and Dueñas, J-M. (2021). Medicinal gardens as an educational strategy in the teaching of the natural sciences: A pedagogical proposal. Research in Social Sciences and Technology, 6(1), 25-39. https://doi.org/10.46303/ressat.2021.2

This is an Open Access article distributed under the terms of the Creative Commons Attribution 4.0 International license (https://creativecommons.org/licenses/by/4.0/).
\end{abstract}

\begin{abstract}
The main aim of this paper was to analyze how medicinal gardens in secondary schools can improve teaching-learning processes in rural settings. The sample comprised 179 students (69.3\% girls) from a rural public secondary school in the province of Huila (Colombia). The age of the participants ranged from 15 to 17 years with a mean of 15.86 years (SD $=0.86$ ). Seeking school motivation strategies for rural students from a rural institution in the municipality of Guadalupe, teachers of the natural sciences designed didactic-pedagogical alternatives employing situated learning that would allow them to contribute to solving school problems and environmental issues affecting rural areas. The environmental phenomena included the loss of fertile soils and the harmful effects of the use of agrochemicals. Medicinal gardens together with situated learning activities proved a useful teaching tool in formal rural educational settings.
\end{abstract}

Keywords: Teaching tools, Medicinal plants, Situated learning, Educational garden

\section{Introduction}

The work of teachers in rural contexts can be challenging, and it involves developing innovative teaching strategies tailored to the cultural environment of the students; because in most cases, it implies teaching classes at two or more educational levels and adapting the contents to the context. Besides, some rural schools in Latin American countries do not have technological tools or the Internet. Within these strategies, it is essential to build and adapt learning 
Reyes, A-E. and Dueñas, J-M. Medicinal gardens as an educational strategy

in the teaching of the natural sciences: A pedagogical proposal

environments that will be accessible to rural students, motivate them, and improve teaching practices (Glover et al., 2016; Mohan et al., 2017). Rural teachers must engage in teaching methods that motivate learning from within the students' context. This allows for the meaningful construction of knowledge throughout the educational community, improving the quality of the pedagogical process. It also encourages students to become involved in their community and environment, which leads them to participate actively, be purposeful, and become transforming individuals (du Plessis \& Mestry, 2019).

Among the most common problems in rural schools is the inability of the education system to motivate students and involve families (du Plessis \& Mestry, 2019). In response to this problem, teachers at the Nuestra Señora del Carmen School from the municipality of Guadalupe HuilaColombia, a rural area, implemented a medicinal school garden. The medicinal school garden and other school gardens were used as an educational tool to foster thinking skills in students. The medicinal garden was a source of meaningful experiences in biology and chemistry revolving around environmental problems in the rural context (e.g. Williams \& Brown, 2013). It is an environmental, pedagogical, and research tool that, in addition to helping to build knowledge, allows young people to create personal care and hygiene products through laboratory practices, with some medicinal applications from botanical extracts (Aguiar et al., 2018). As such, the main objective of this study was to design and implement a pedagogical strategy focused on the development of scientific competencies and environmental skills through the recovery of ancestral practices associated with plants. The present pedagogical proposal is founded on social constructivist approaches that establish situated learning from the theoretical perspective of Vygotsky (Fosnot, 2005). In turn, this perspective is based on the role of culture in the development of people's higher mental processes, giving special importance to the relationships between the individual and society (Wright, 2018). In this way, situated learning is based on the belief that skills and knowledge are linked to the situation in which they are learned, that is, to real daily problems or situations. This type of learning refers to the socio-cultural context as a critical element for the acquisition of skills and competencies (Woolfolk, 2006; Yeoman \& Wilson, 2019). More specifically, learning, and primarily scientific learning, often contains a social component (Levinson \& Consortium, 2017; Mishra, 2014), which is linked to specific contexts and historical periods (O'Brien \& Battista, 2020; Sorensen et al., 2005). It is for this reason that acquiring scientific skills involves moving from a scientific problem to a social problem, from an individual interest to a collective interest, from thought to action, from encyclopedic knowledge to the understanding and assimilation of knowledge. Because learning, especially in relation to science, has a social component. Ávila et al. (2007) suggests that science is part of the daily lives of individuals. However, sometimes the presence of science is not as evident as the presence of technology. In fact, different researchers consider the science, technology, society, and environment education (STSE) perspectives as a current approach to developing high-level abstraction skills in students that allow them to access critical thinking. Specifically, different studies have proven the effectiveness of this approach; for example, the data reported by Avery, 2013, suggests that rural contexts can be rich environments for learning science using traditional and local knowledge for science education. In this sense, a study aimed to investigate the effects on understanding by high school students using an STSE approach on chemistry topics by establishing relationships between Science, 
Reyes, A-E. and Dueñas, J-M. Medicinal gardens as an educational strategy

in the teaching of the natural sciences: A pedagogical proposal

Technology, Society, and Environment. The results revealed statistically significant increases in achievement levels compared to traditional types of teaching (Yörük et al., 2010). It is undeniable that collective knowledge changes over time (Kimmerle et al., 2010), and what is acceptable at one time and place can become wrong at another time and place, or unnecessary to learn due to socio-cultural changes. Furthermore, social needs make specific knowledge and skills essential (Saini, 2000). That is the case of rural communities, which have specific characteristics that must be taken into account in the teaching-learning processes of educational institutions.

Therefore, situated learning is ideal in rural populations because it takes into account the needs of the student body based on their context; those students living in the rural areas of Guadalupe-Huila-Colombia may benefit from an explanation focused on the cultivation and farming of grain, as this experience is engrained in their lives; analogies based on this type of farming may be less effective in an urban context where students possibly have less experience with farming in general. Situated learning or cognition is understood as a teaching methodology based on specific and real situations within a specific socio-cultural context, where the student must seek theoretical applicability to diverse everyday situations (Bloch et al., 1994; Silva, 2013). According to this approach, learning must be active and take place in a real environment, which fosters transformation and change both in the students and in the context in which it takes place (Wright, 2018). Context-sensitive teaching-learning processes are more likely to produce understanding that will become apparent in the competent performance of the learner (McLellan, 1996; O’Brien \& Battista, 2020).

This study emanated from the need to develop motivational teaching strategies that would encourage students at a rural school to improve their learning processes and to build scientific knowledge based on environmental problems combined with their prior knowledge of their socio-environmental context. To this end, a medicinal school garden was planted that allowed students to activate their previous knowledge of natural sciences and interact with their communities in relation to plant cultivation.

The process of sowing and harvesting medicinal plants from the school garden offered students a pedagogical strategy that helped in the development of curricular topics in the subjects of biology and chemistry at different academic levels. It became an educational tool that enhanced the students' learning processes and helped to develop their scientific knowledge from within their socio-cultural and environmental context.

This rural pedagogical initiative was of great importance for the educational and rural community because it helped reduce the organic waste disposed of in the environment through the production of effective, organic, and environmentally friendly fertilizers. These fertilizers were produced by the students and helped raise awareness among the population of proper environmental management strategies, including avoiding the use of agrochemicals. The implementation of this educational tool also sought to generate life options for the students, given the harsh social and economic conditions experienced by many young people in rural communities, especially women, who do not have a secure place in agricultural work. 
Reyes, A-E. and Dueñas, J-M. Medicinal gardens as an educational strategy

in the teaching of the natural sciences: A pedagogical proposal

\section{The present study}

The main aim of this research is to analyze, by means of a pedagogical strategy, how medicinal gardens in schools can improve teaching-learning processes in rural secondary schools. This pedagogical strategy had the following two objectives: 1) develop the curricular contents of several subjects (natural sciences, chemistry and social sciences) by implementing, tending and maintaining a school garden, establishing laboratory practices, and ascertaining popular knowledge of plants; 2 ) raise awareness among the educational community of the importance of caring for and preserving natural resources and cultural wealth as it relates to plant use. This proposal is considered innovative because it focuses on a disadvantaged rural environment. Few studies or pedagogical practices have addressed school gardens in poor rural populations. Moreover, it provides information on how to implement school gardens that focus on the school curriculum. Several studies have shown how school gardens can benefit students, for example by having positive impacts on student health. School gardens can also influence student and teacher perceptions of academic achievement (Ohly et al., 2016), which may also increase students' motivation to actively participate in educational processes. Moreover, as green spaces that comprise plants, grass and shrubs are associated with academic achievement (Kweon et al., 2017), the level of student absenteeism or dropout is expected to decrease. From the above literature, we expect that students who participate in the pedagogical strategy based on medicinal gardens will obtain higher scores than previous students. We also anticipate that they will become involved in environmental issues and that they will assimilate the knowledge they acquire from the rural community in which their educational institution is located. The relationships between schools, families and communities are essential to the education of students (Camarero-Figuerola et al., 2020). More in-depth family and community engagement provides an essential opportunity for schools to enhance school curricula (Đurišić \& Bunijevac, 2017)

\section{Method}

This research adopted an exploratory-descriptive approach (Canales Cerón, 2006) to associate the previous knowledge of the students at the school with their families and their social and academic environment. It takes as a starting point various ancestral practices of the poorer communities in the region, which are associated with medicinal plants from these communities in the municipality of Guadalupe-Huila-Colombia. According to Bravo et al. (2016), the constructivist didactics of natural sciences in rural educational contexts has a dual theoretical purpose. First, it encourages the acquisition and enhancement of academic knowledge and second, it regulates and guides the practice of teaching-learning by developing proposals for intervening in and transforming the reality of young people from lower-income communities.

\section{Participants}


Reyes, A-E. and Dueñas, J-M. Medicinal gardens as an educational strategy

in the teaching of the natural sciences: A pedagogical proposal

The aim of this study was to implement a pedagogical strategy with secondary school students. It was therefore carried out in two academic years (2017 and 2018). The sample comprised 179 students (69.3\% girls) from a rural public secondary school in the province of Huila (Colombia). The age of the participants ranged from 15 to 17 years with a mean of 15.86 years $(S D=0.86)$. All students studied chemistry and social sciences simultaneously.

\section{Instruments}

The pedagogical strategy for action included in this project revolves around several problems in the rural context. The design and execution of these proposals included: 1) Creating, maintaining and harvesting the school's medicinal garden for consumption by the educational community in general, and with input from the chemistry and biology laboratories. 2) Developing curricular topics in biology and chemistry, as well as science laboratory practices, all associated with the cultural and environmental context of the students. 3) Developing entrepreneurial foundations with the adoption of academic laboratory practices based on resources offered by the environment and the cultural knowledge of the community. 4) Promoting the cross-disciplinarily of curricular topics within the subjects of biology, chemistry, and social studies with laboratory practices and entrepreneurial techniques from botanical extracts obtained from medicinal plants for the purpose of developing thinking skills, science skills, and communication skills. In this pedagogical strategy, the plants of the medicinal garden became educational contextual tools that also offered content and natural chemical reagents for the development of organic chemistry laboratory guides since they were used to create natural chemical products with, for example, therapeutic, beauty and personal hygiene applications. In the laboratory practices, students expanded their existing knowledge from experiences nurtured with widespread knowledge from the community on the medicinal plants of the region. To develop the laboratory guides, students obtained various botanical extracts from the medicinal garden, which they used to manufacture all kinds of products with commercial and medicinal use, such as perfumed talc, fruit, floral and citrus soaps, and exfoliates, all of which were based on plants and natural extracts. Herbal, floral, and fruit ointments, creams, and tonics were also manufactured (see Figure 1).

Organic chemistry practices, in which natural personal hygiene products were made with botanical extracts, were combined with laboratory experiments by engaging in discussion forums and debates, raising awareness of the ecosystem services of aromatic plants, and addressing maintenance and care techniques for the medicinal garden. These included composting processes, observation of ecological interactions, preparation of organic pesticides from plant extracts (tobacco, chili, and garlic), recovery of infertile soils, and proper use of agrochemicals. Table 1 outlines the teaching strategies employed. 
Reyes, A-E. and Dueñas, J-M. Medicinal gardens as an educational strategy in the teaching of the natural sciences: A pedagogical proposal

Table 1

Pedagogical strategy

\begin{tabular}{|c|c|}
\hline Activity & Purpose \\
\hline \multirow{3}{*}{$\begin{array}{l}\text { Planting, care, and } \\
\text { harvesting of the } \\
\text { vegetable gardens }\end{array}$} & $\begin{array}{l}\text { 1) To maintain medicinal gardens for the consumption of the } \\
\text { educational community and develop academic laboratory } \\
\text { practices }\end{array}$ \\
\hline & $\begin{array}{l}\text { 2) To develop environmental awareness, knowledge of } \\
\text { ecosystem services, agroecology, and biocontrol of pests }\end{array}$ \\
\hline & 3) To develop science and thinking skills \\
\hline \multirow[t]{2}{*}{$\begin{array}{l}\text { Waste management of } \\
\text { the school restaurant } \\
\text { and preparation of } \\
\text { organic fertilizers }\end{array}$} & $\begin{array}{l}\text { 1) To produce at least } 10 \text { kilos of organic fertilizer every two } \\
\text { months to strengthen the school medicinal garden and } \\
\text { encourage decrease in the use of agrochemicals by the rural } \\
\text { community surrounding the educational institution }\end{array}$ \\
\hline & 2) To foster the recovery of infertile soils \\
\hline \multirow{7}{*}{$\begin{array}{l}\text { Development of a } \\
\text { meaningful pedagogical } \\
\text { experience }\end{array}$} & $\begin{array}{l}\text { 1) To create strategies for improving the teaching and learning } \\
\text { processes in the natural sciences }\end{array}$ \\
\hline & $\begin{array}{l}\text { 2) To improve communication between learners and family } \\
\text { members }\end{array}$ \\
\hline & $\begin{array}{l}\text { 3) To create natural products with beauty and therapeutic } \\
\text { applications }\end{array}$ \\
\hline & 4) To develop science and entrepreneurial skills \\
\hline & $\begin{array}{l}\text { 5) To empower lower-income communities to take advantage of } \\
\text { their cultural richness and plant knowledge }\end{array}$ \\
\hline & 6) To solve problems in the rural context \\
\hline & $\begin{array}{l}\text { 7) To promote pedagogical practices that cross over to other } \\
\text { areas of knowledge and to the knowledge of rural communities }\end{array}$ \\
\hline
\end{tabular}

\section{Data collection}

Teacher's diary reflections. The teacher's diary refers to the notes taken by a teacher after observing or self-observing a class. It enables the teacher to reflect on the most relevant processes and interactions conducted in a class, including personal reactions.

State test scores. We used the students' scores on "pruebas saber" to compare results obtained by groups that participated in the pedagogical strategy with those obtained by previous groups that did not. These "pruebas saber" are standardized external tests run by the Colombian Institute for the Evaluation of Education (ICFES, for its acronym in Spanish) to evaluate student 
Reyes, A-E. and Dueñas, J-M. Medicinal gardens as an educational strategy

in the teaching of the natural sciences: A pedagogical proposal

performance at the end of each educational cycle in accordance with the fundamental competencies established by the Colombian Ministry of Education.

\section{Results}

\section{Results of pedagogical practice}

Students need to learn the importance of caring for the environment, so this project aimed to raise awareness among the community and the educational community about the importance of caring for and preserving natural resources and cultural wealth as it relates to plant use. To that end, the lead teachers of the Student Social Service focused on training these communities with the support of students in the last two years of secondary school. The students held informative talks in the rural communities where they live, where they highlighted the importance of the medicinal garden, ecosystem services and the preparation of insecticides from botanical extracts.

Another contribution of this process was to reduce the contamination of water bodies by making natural herbal soaps from recycled cooking oil and botanical extracts, which were marketed at local and regional peasant fairs. One of the positive effects included the training given by the student social service to the rural communities of Guadalupe on the appropriate management of agrochemicals, the use of controllers, and insecticides based on botanical extracts, as well as on the importance of genotypic and neurotoxic effects from the handling of herbicides (derived from glyphosate).

Another result that generated an impact was training and awareness-raising in the sustainable use and management of the region's natural plant resources through workshops and talks given by the students, who fed their learning back to their local communities by instructing them in techniques for the handling, use, conservation, preservation, marketing, and sale of botanical specimens. In the workshops, we worked with various medicinal plants for therapeutic uses and the preparation of several aromatic drinks, including coffee, given that the educational institution is located in a traditional coffee-producing area. Each package describes the medicinal and therapeutic properties that the communities report in the area, as well as some properties reported in the scientific literature.

Developing meaningful experiences inside and outside the classroom during these learning processes positively affected the results of the activities conducted in this educational project. The entrepreneurial action involved in this academic effort is reflected in the development of personal care products, such as soaps and shampoos, fragrances and perfumes made from the essential oils of aromatic plants, and medicinal ointments and other products made from botanical extracts from the school's medicinal garden. Similarly, beverages prepared from aromatic plants were considered alternative treatments for various ailments suffered by members of the community. In general, learning the techniques for drying and storing medicinal plants and extracting natural chemical substances from organic solvents was an important student exercise (see Figure 1). The steps taken to create a school garden are described in the Appendix. 
Reyes, A-E. and Dueñas, J-M. Medicinal gardens as an educational strategy in the teaching of the natural sciences: A pedagogical proposal

\section{Figure 1}

\section{Students preparing medicinal products and participating in regional fairs}

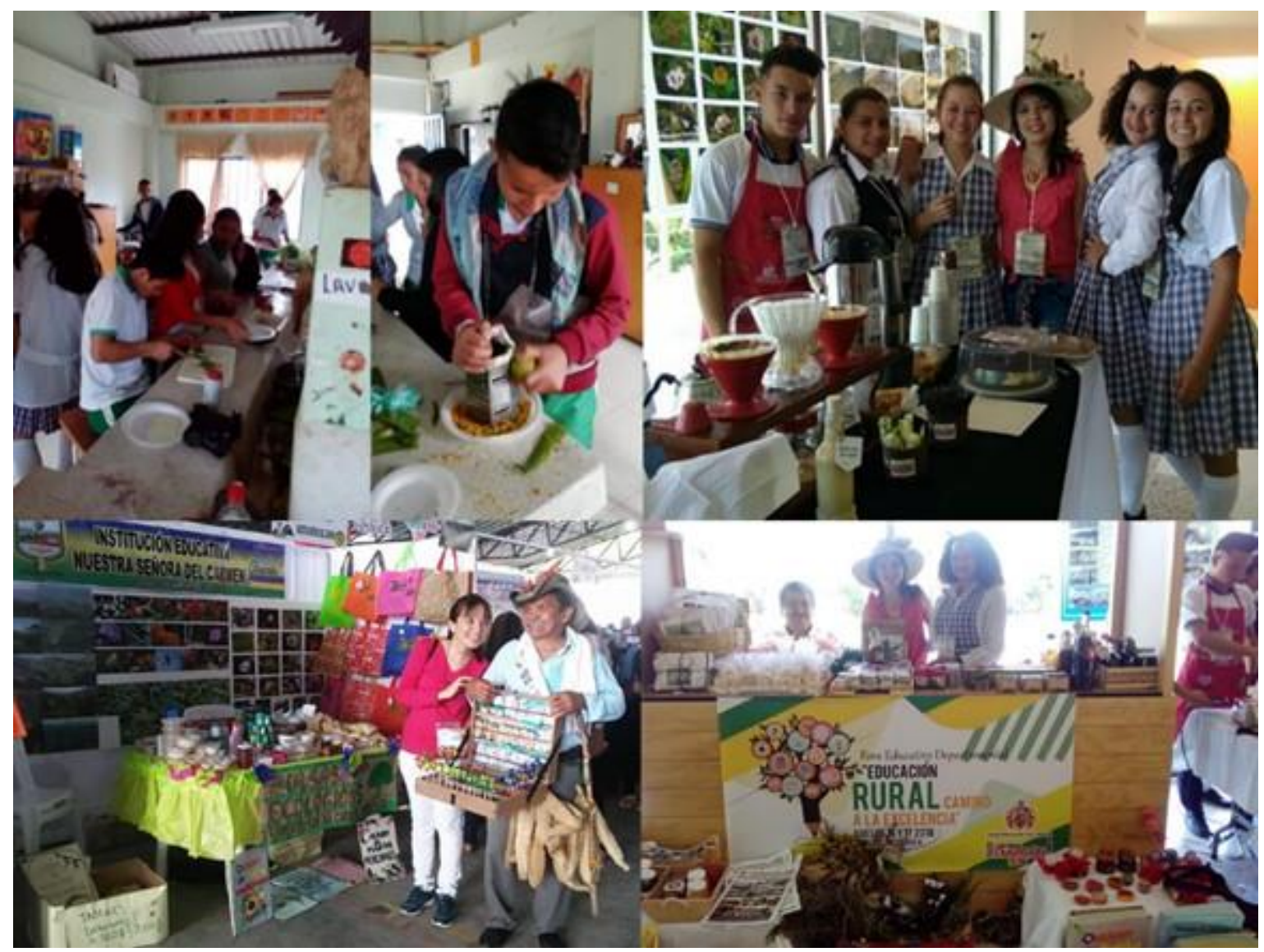

\section{State test scores}

Among the most relevant results of the study is the improvement in state testing results in recent years. A significant increase in test scores seen since 2018 consists of approximately two additional points per year, which is evidence of the success of this experience. We obtained these data from the compulsory state tests carried out in the last year of secondary education for all Colombian students. Specifically, the overall average for the 2016 academic year was 215; in contrast, the average for the 2017 and 2018 academic years was 227. Although in 2018, no improvement was obtained in the overall average, it was maintained, which is a positive result. In addition, the results on the internal tests and exams periodically given to the students showed improvement and demonstrated the empowerment of the students in their learning processes, especially in the experimental and procedural parts. For example, students were able to design experiments to test the theory presented in textbooks based on the rules, procedures, abilities, and skills in natural sciences and chemistry. In the feedback the students 
Reyes, A-E. and Dueñas, J-M. Medicinal gardens as an educational strategy

in the teaching of the natural sciences: A pedagogical proposal

gave at the end of each syllabus, they expressed feeling more curious and keener to check the theories studied.

Among their reflections was the perception of greater interest in learning the processes involved in the natural sciences and in building scientific knowledge from the traditional and cultural knowledge associated with medicinal plants. These results were obtained from school surveys administered to the students. Specifically, the students were asked about their level of motivation for each subject. In general, over $62.3 \%$ of students affirmed that they felt motivated by attending natural sciences and chemistry classes.

\section{Discussion}

The results obtained in this research respond to the design of teaching strategies that sought to improve learning processes in the natural sciences in rural students from a rural school in southern Huila. The students and the educational community in general showed enthusiasm when engaging, valuing, and recognizing the knowledge of their local communities, giving meaning to what they learn in their academic activities.

Our results coincide with those of previous works in which pedagogical strategies were used to improve the learning processes for natural sciences content.

In contrast to previous studies, our study attempted to generate new tools in which strategies were implemented that sought to strengthen thinking and science skills in the area of chemistry and environmental education while seeking to generate entrepreneurial skills in rural students. According to García Parrado (2015), it is necessary to encourage entrepreneurship in school practices, because it is a strategy to strengthen capacities in individuals, through selfmanagement and the projection of each subject on their environment. This is possible through the re-creation of environments for the generation of entrepreneurial attitudes from the classroom, also generating significant learning and connections with other areas of knowledge.

Education in rural contexts poses increasingly demanding challenges due to the continuous changes and globalization undergone by rural communities in developing countries. The Colombian rural world is a social, economic, and cultural amalgam where full-time farming households coexist within a complex economic panorama side by side with impoverished families immersed in historical conflicts of violence. This historical situation of the rural environment and its dynamics of abandonment by institutions are juxtaposed with globalization as multiple processes are progressively established through companies, global entities, and private and governmental institutions that determine the capacity to face new challenges. These organizations have created the expectation that educational processes should offer the tools to generate opportunities for young people in a landscape where such opportunities are becoming increasingly scarce. The educational system has not been very effective in presenting these types of tasks due to a limited capacity to motivate the generation of alternative paths toward entrepreneurship (Martínez Rodríguez \& Bustos Jiménez, 2011). 
Reyes, A-E. and Dueñas, J-M. Medicinal gardens as an educational strategy

in the teaching of the natural sciences: A pedagogical proposal

On the other hand, the implementation of medicinal school gardens as pedagogical and didactic tools is a trend recognized even by the United Nations Food and Agriculture Organization, which maintains that "school gardens are a learning strategy advantageous to improve education and nutrition." They also promote the conservation of the environment and the well-being of the entire educational community (Olcoz Izura, 2015). In addition to the above, the school's medicinal garden provides a platform for meaningful learning, science skills, and thinking skills through classroom activities and laboratory practices, which are mainstream and revolve around the medicinal plants of the region (Bernardon et al., 2014; Zbynek Vacha, 2018).

Regarding the development of science and thinking skills, our results found that students understood and were able to apply the scientific knowledge learned through the design and construction of natural, medicinal, and personal hygiene products from botanical extracts obtained from the garden. Scientific knowledge is understood as a set of verifiable facts supported by evidence collected by scientific theories (Persoon et al., 2020). At the procedural level, this shows that students are capable of solving a problematic situation characteristic of their context, as they apply their knowledge to the needs of their community. At the same time, the project encouraged collaborative work similar to that described by Vera Espitia (2015), the author who designed a pedagogical proposal based on school gardens and evidenced an improvement in the level of knowledge and apprehension of the conceptual, attitudinal, and procedural contents. According to the author, the teaching of ecosystems can be guided from the school garden, a strategy that allows students to improve cognitive skills since it allows them to directly access the concepts.

The medicinal garden, in addition to being a teaching tool, provided an approach to understanding environmental problems because it allowed students to be in contact with the ecological variables that can be verified by means of the scientific method, which led them to ask questions about problems that directly affect ecosystem services, insecticide resistance, the loss of fertile soils and climate change, among others. This data was then collected through meetings with teachers; however, more empirical studies are needed to help support these conclusions.

The project also provided a framework for meaningful experiences during the learning processes outside and within the classroom. It yielded positive responses of participation for all students in the results obtained during the development of the educational project. This points to the success of the entrepreneurial action applied in this academic effort, represented by the preparation of personal-care products, such as soap and shampoo, medicinal ointments from botanical extracts from the medicinal garden, and fragrances and perfumes based on essential oils from aromatic plants, which were later marketed at fairs (see Figure 1).

Another outstanding achievement within the educational community was the preparation of nutritious beverages from aromatic plants. As an alternative treatment to various ailments in the members of the community, the use of aromatic plants as natural additives was also recognized as a means to improve the operability of food at the school cafeteria. The approach of this educational project has contributed to the interrelation and exchange of knowledge among students, community members, and teachers from the secondary educational 
Reyes, A-E. and Dueñas, J-M. Medicinal gardens as an educational strategy

in the teaching of the natural sciences: A pedagogical proposal

institution of a school in the municipality of Guadalupe. Its agro-environmental theme provided a route by means of which solutions to environmental situations could be strengthened, while at the same time generating business alternatives and a vision of conservation and recovery of local natural resources.

\section{Conclusion}

This process brought the entrepreneurial action led by an educational institution to the forefront, which united efforts between students, the community, and teachers to develop strategies to improve the quality of life of students and the community of a Colombian rural area abandoned by the government. The project gave rise to proposals for the conservation of natural resources and provided a platform for the training of students and the community in situations applicable to the real situations they live in, which aimed to generate positive sociocultural changes.

Our proposal has some limitations. First, we did not collect objective data on the different steps of the project, and it is necessary that future studies analyze each step to learn more about the benefits of school medicinal gardens in teaching and learning about the natural sciences and chemistry. Second, our data has been analyzed as a group, which has not allowed us to carry out robust statistical analyses that would enable us to explain the benefits of this pedagogical proposal individually.

\section{References}

Aguiar, N. C. de S., Ramos, M. A., \& Fernandes, M. L. B. (2018). An Analysis on the Importance of Medicinal Garden as Teaching Resource in A School in Northeast of Brazil. Asian Journal of Applied Sciences, 6(6). https://doi.org/10.24203/ajas.v6i6.5589

Avery, L. M. (2013). Rural Science Education: Valuing Local Knowledge. Theory into Practice, 52(1), 28-35. https://doi.org/10.1080/07351690.2013.743769

Ávila, F., Bautista, S., Betancourt, J., Calderón, J., \& Triana, C. G. R. (2007). Ciencia y cotidianidad, competencias culturales básicas. X Reunión de La Red de Popularización de La Ciencia y La Tecnología En América Latina y EI Caribe (RED POP - UNESCO) y IV Taller "Ciencia, Comunicación y Sociedad," 1-12. https://www.cientec.or.cr/archivo/pop/2007/CO-JulianBetancourt.pdf

Bernardon, R., Schmitz, B. de A. S., Recine, E. G. I., Rodrigues, M. de L. C. F., \& Gabriel, C. G. (2014). School Gardens in the Distrito Federal, Brazil. Revista de Nutricao, 27(2), 205216. https://doi.org/10.1590/1415-52732014000200007

Bloch, M., Lave, J., \& Wenger, E. (1994). Situated Learning: Legitimate Peripheral Participation. Man, 29(2), 487. https://doi.org/10.2307/2804509

Bravo, A. A., Ramírez, G. P., Faúndez, C. A., \& Astudillo, H. F. (2016). Propuesta didáctica constructivista para la adquisición de aprendizajes significativos de conceptos en física 
Reyes, A-E. and Dueñas, J-M. Medicinal gardens as an educational strategy in the teaching of the natural sciences: A pedagogical proposal

de fluidos. Formacion Universitaria, 9(2), 105-114. https://doi.org/10.4067/S071850062016000200012

Camarero-Figuerola, M., Dueñas, J.-M., \& Renta-Davids, A.-I. (2020). The relationship between family involvement and academic variables. Research in Social Sciences and Technology, 5(2), 57-71. https://doi.org/10.46303/ressat.05.02.4

Canales Cerón, M. (2006). Metodologías de investigación social. Introducción a los oficios. LOM Ediciones, 406. https://doi.org/10.1017/СBO9781107415324.004

du Plessis, P., \& Mestry, R. (2019). Teachers for rural schools - a challenge for South Africa. South African Journal of Education, 39(Supplement 1), S1-S9.

https://doi.org/10.15700/saje.v39ns1a1774

Đurišić, M., \& Bunijevac, M. (2017). Parental involvement as a important factor for successful education. CEPS Journal, 7(3), 137-153.

https://www.cepsj.si/index.php/cepsj/article/view/291

Fosnot, C. (2005). Constructivism : theory, perspectives, and practice. Teachers College Press.

García Parrado, F. A. (2015). Emprender desde la escuela, aportes a la formación para el emprendimiento desde la Pedagogía por Proyectos. EDUCACIÓN Y CIENCIA, O(16). https://doi.org/10.19053/01207105.3238

Glover, T. A., Nugent, G. C., Chumney, F. L., Ihlo, T., Shapiro, E. S., Guard, K., Koziol, N., \& Bovaird, J. (2016). Investigating Rural Teachers' Professional Development, Instructional Knowledge, and Classroom Practice. Journal of Research in Rural Education, 31(3), 1-16. https://eric.ed.gov/?q=Rural+teachers\&ff1=dtySince_2016\&id=EJ1101917

Kimmerle, J., Moskaliuk, J., Harrer, A., \& Cress, U. (2010). Visualizing co-evolution of individual and collective knowledge. Information Communication and Society. https://doi.org/10.1080/13691180903521547

Kweon, B. S., Ellis, C. D., Lee, J., \& Jacobs, K. (2017). The link between school environments and student academic performance. Urban Forestry and Urban Greening, 23, 35-43. https://doi.org/10.1016/j.ufug.2017.02.002

Levinson, R., \& Consortium, T. (2017). Socio-scientific Inquiry-Based Learning: Taking off from STEPWISE (pp. 477-502). Springer, Cham. https://doi.org/10.1007/978-3-319-555058_22

Martínez Rodríguez, J. B., \& Bustos Jiménez, A. (2011). Globalization, new ruralities and schools. Profesorado, Revista de Currículum y Formación Del Profesorado, 15(2). https://recyt.fecyt.es/index.php/profesorado/article/view/43409

McLellan, B. (1996). Situated Learning: Multiple Perspectives. In Situated Learning Perspectives.

Mishra, R. K. (2014). Social Constructivism and Teaching of Social Science. In www.sosyalbilgiler.org Journal of Social Studies Education Research Sosyal Bilgiler Eğitimi 
Reyes, A-E. and Dueñas, J-M. Medicinal gardens as an educational strategy in the teaching of the natural sciences: A pedagogical proposal

Araştırmaları Dergisi (Vol. 2014, Issue 2). www.sosyalbilgiler.org

Mohan, P. P., Lingam, G. I., \& Chand, D. D. (2017). A comparative study of rural and urban teachers' perceptions of professional development. Waikato Journal of Education, 22(4), 79-87. https://doi.org/10.15663/wje.v22i4.352

O'Brien, B. C., \& Battista, A. (2020). Situated learning theory in health professions education research: a scoping review. Advances in Health Sciences Education, 25(2), 483-509. https://doi.org/10.1007/s10459-019-09900-w

Ohly, H., Gentry, S., Wigglesworth, R., Bethel, A., Lovell, R., \& Garside, R. (2016). A systematic review of the health and well-being impacts of school gardening: Synthesis of quantitative and qualitative evidence. BMC Public Health, 16(1), 286. https://doi.org/10.1186/s12889-016-2941-0

Olcoz Izura, I. (2015). Valoración del huerto escolar como herramienta de enseñanzaaprendizaje. http://uvadoc.uva.es/handle/10324/13434

Persoon, P. G. J., Bekkers, R. N. A., \& Alkemade, F. (2020). The science base of renewables. Technological Forecasting and Social Change, 158, 120121. https://doi.org/10.1016/j.techfore.2020.120121

Saini, A. (2000). Literacy and Empowerment: An Indian Scenario. Childhood Education. https://doi.org/10.1080/00094056.2000.10521186

Silva, G. (2013). La vida cotidiana como práctica de aprendizaje en los alumnos del CCH. Eutopia, 6(19), 118-122.

Sorensen, E. W., Haugbolle, L. S., Herborg, H., \& Tomsen, D. V. (2005). Pharmacy education : an international journal for pharmaceutical education. Pharmacy Education, 5(4). https://pharmacyeducation.fip.org/pharmacyeducation/article/view/180

Vera Espitia, J. A. (2015). La huerta escolar como estrategia didáctica para el desarrollo de competencias científicas en la institución educativa maestro pedro nel gómez [Universidad Nacional de Colombia]. http://bdigital.unal.edu.co/48064/1/80420453.2015.pdf

Williams, D. R., \& Brown, J. D. (2013). Learning gardens and sustainability education: Bringing life to schools and schools to life. In Learning Gardens and Sustainability Education: Bringing Life to Schools and Schools to Life. Routledge. https://doi.org/10.4324/9780203156810

Woolfolk, A. (2006). Psicología educativa (9th ed.). Pearson Educación.

Wright, D. E. (2018). Situated Learning. In Active Learning (pp. 70-95). https://doi.org/10.4324/9781315743141-5

Yeoman, P., \& Wilson, S. (2019). Designing for situated learning: Understanding the relations between material properties, designed form and emergent learning activity. British Journal of Educational Technology, 50(5), 2090-2108. 

in the teaching of the natural sciences: A pedagogical proposal

https://doi.org/10.1111/bjet.12856

Yörük, N., Morgil, I., \& Seçken, N. (2010). The effects of science, technology, society, environment (STSE) interactions on teaching chemistry. Natural Science, 02(12), 14171424. https://doi.org/10.4236/ns.2010.212173

Zbynek Vacha, J. . (2018). Inquiry based education at primary schools through school. Journal of International Scientific Publication, 11(2), 219-230. 
Reyes, A-E. and Dueñas, J-M. Medicinal gardens as an educational strategy in the teaching of the natural sciences: A pedagogical proposal

\section{Appendix 1}

\begin{tabular}{ll}
\hline \multicolumn{1}{c}{ Step } & \multicolumn{1}{c}{ Pedagogical activities } \\
\hline Sowing and & $\begin{array}{l}\text { - The teachers taught the correct way to prepare the } \\
\text { land and prepare compost from organic waste from } \\
\text { the kitchen. } \\
\end{array}$ \\
& - The students interviewed older adults about \\
& ethnobotanical knowledge and the search for \\
botanical specimens with medicinal uses. & \\
& - The students, with the guidance of the teachers, \\
& carried out the planting of botanical specimens on \\
& the ground prepared with organic fertilizer.
\end{tabular}

$\begin{array}{ll}\text { Harvest and } & \text { - Under the direction of the teachers, the students } \\ \text { Drying } & \text { identified and socialized the medicinal properties of } \\ \text { botanical specimens from the garden, typical of the } \\ \text { region where the school is located. } \\ \text { - The teachers developed Biology and Chemistry } \\ \text { classes around ancestral knowledge of medicinal } \\ \text { plants. } \\ \text { - The students carried out the harvest of plant } \\ \text { material intended for laboratory practices in biology } \\ \text { and chemistry. }\end{array}$

Laboratory

- In the laboratory classes, the students made

practices handcrafted hygiene, beauty, and medicinal products. The practical classes were carried out employing the construction of scientific knowledge from the school laboratory practices.

- A seminar was held to socialize the scientific results obtained and to analyze the ethnobotanical knowledge of the community.

Procedure for the application of the pedagogical proposal 